\title{
COVID-19 pandemic and construction industry: impacts, emerging construction safety practices, and proposed crisis management framework
}

\author{
Muzaffar Iqbal' ${ }^{1}$, Naveed Ahmad², Muhammad Waqas³, Maira Abrar \\ ${ }^{1}$ Tianjin University, College of Management and Economics, Tianjin, P. R. China. \\ ${ }^{2}$ Northwestern Polytechnical University, School of Management, Xi'an, P. R. China. \\ ${ }^{3}$ Xi'an Jiaotong University, School of Economics and Finance, Xi'an, P. R. China. \\ ${ }^{4}$ Konkuk University, School of Business Administration, Seoul, South Korea.
}

How to cite: Iqbal, M., Ahmad, N., Waqas, N. et al. (2021), “COVID-19 pandemic and construction industry: Impacts, emerging construction safety practices, and proposed crisis management framework", Brazilian Journal of Operations \& Production Management, Vol. 18, No. 2, e20211157. https://doi.org/10.14488/BJOPM.2021.034

\section{ABSTRACT}

Goal: COVID-19 has a drastic effect on world economic progress and different industries. As the main contributor to countries' economies, the construction industry faced multiple challenges due to pandemics. Therefore, it's essential to identify the impact of COVID-19 on the construction sector and develop safety practices in construction processes. This study proposed necessary construction practices and a crisis management framework needs to adopt in the COVID-19 scenario.

Design / Methodology / Approach: At the first stage, data on negative impacts on the construction industry due to the pandemic was compiled. Then, experts were invited to propose emerging safety measures and practices to improve the safety of construction employees. Lastly, crises management framework was proposed, which provides an increased capability of taking measures during and after the COVID-19 pandemic.

Results: Results showed that COVID-19 has an adverse effect on the construction sector of different developed and developing countries. Therefore, there is a need to incorporate proposed safety practices at construction sites and apply crises management framework to increase construction productivity during the pandemic.

Limitations of the investigation: This study has certain limitations for instance the availability of data regarding construction sector was limited especially about small countries whose economies are not fully documented and construction sector is not regulated. The evaluation and assessment made in this study were generally subjective and it cannot be generalized to other sectors. This work could insist on enhancing the work plan for the future to encounter the uncertain circumstances for construction industry.

Practical implications: This work will be useful for construction managers and policy makers to cope with COVID-19 and to adopt necessary safety measure for construction sector. This work also be helpful for other industry stakeholders to pinpoint risk management efforts that could be suitable for their firms. industrialists may use these research efforts to sort out the problem areas and propose an appropriate framework for industry.

Originality / Value: This study will provide guidelines to construction professionals for taking necessary measures to cope with COVID-19 and to apply a crises management framework.

Keywords: COVID-19; Measures; Safety Guidelines; Crises Management Framework; Construction Industry.

Financial support: None

Conflict of interest: The authors have no conflict of interest to declare.

Corresponding author: waqasalyani23@gmail.com

Received: 28 January 2021

Approved: 5 May 2021

Editor: Syed Abdul Rehman Khan. 


\section{INTRODUCTION}

The coronavirus, which is known as (COVID-19) pandemic, has brought significant challenges to the development of the world economy and has an unprecedented impact on the construction industry (Alsharef et al., 2021). The impact of Covid-19 has disturbed industrial sectors; especially, the construction industry is badly affected by the adverse impacts (Ogunnusi et al., 2020). Apart from job risk, workers and professionals who perform their duties on construction sites are at high risk of exposure and infection from aerosol and droplet contamination (Zheng et al., 2020). Specific data on the risk of infection about workers is not available, which is a major concern for the construction sector. The slow progress of the construction sector in the crisis of COVID-19 grabs the attention of stakeholders (Gamil and Alhagar, 2020). The construction industry business is at risk because of the adverse impact of COVID-19 that leads to a decrease in economic growth. The restrictions on construction projects due to the pandemic crisis has weakened economic growth, enhanced unemployment, disturbed supply chain of construction materials, and increased the loss of investment (Bsisu, 2020). It has been estimated that international construction growth in the current year has been lessened from 3.1\% to 0.5\% (Global Data, 2020). Unfortunately, the crisis of the construction industry in COVID-19 develops an unprecedented opportunity to resolve the critical issues that belongs to the construction industry. The stakeholders of the construction sector, such as builders, contractors, and owners, faced the crisis of COVID-19 at a global level (Ogunnusi et al., 2020). The crisis of this pandemic situation grabbed the attention of stakeholders to concentrate on the long-term and short-term strategies that may help to overcome the drastic situation of COVID-19 globally. The COVID-19 crisis has led construction companies towards adopting long term strategic goals for the construction sector and developing best safety practices that could help workers continue the work activities in the pandemic situation (Afkhamiaghd and Elwakil, 2020).

Relevant literature about coronavirus is quite enough for further studies. The domain of academic meadow of research is paying attention to Covid-19. However, it's just a growing and fast-developing field. Safety in construction projects has been considering a major issue for practitioners. The assistance of previous studies to cope up the issues of safety practices and their recommendations are designed to further stimulate academic investigation into the safety impacts of this pandemic. This could be significant to address the safety measures in the face of this pandemic situation. Earlier studies on developing measures to cope COVID-19 pandemic in the construction sector describe that proactive risk classification, map the corporate supply chain, potential development of innovative technologies and plan alteration could be effective in fighting against COVID-19 pandemic (Zhu et al., 2020). Block chain is a technology with a unique combination of features such as decentralized structure etc. Block chain has immense potential to transform supply chain functions through enhanced visibility and business management (Dutta et al., 2020). During the COVID-19 pandemic, blockage of people and material movement disrupted every supply chain (Khan et al., 2020). Literature preview on humanitarian supply chains and logistics management Van der Laan et al. (2016) suggests a resilient supply chain that will help the construction industry to operate smoothly during the COVID-19 pandemic or any other shock. Those firms which follow a resilient supply chain will be best positioned in any case (Schatteman et al., 2020; Yu and Rehman Khan, 2021). Adoption of industry 4.0 technologies brings significant improvements for all performances (Brunheroto et al., 2021). With the beginning of the industry 4.0 era, there is an emphasis on technology in every field, and block chain technology is found vital to play a positive role in the circular economy (Rehman Khan et al., 2021). As advanced technology plays a vital role in supply chain operations especially, in COVID-19 artificial intelligence, machine learning, 5-G technology, and block chain will calibrate supply with more realistic forecast demand (Schatteman et al., 2020).

Some data regarding the adverse impact of COVID-19 in the perspective of global construction industry exist also some remains unexplored. Insights from construction sector investors are especially lacking in wide range of literature. Therefore, this work focusing to 
sort out the helpful information regarding the impact of COVID-19 on construction sector, safety practices and a suggested framework of crisis management. This research also focused to finds new ways that may help stakeholders and other concerned authorities to encounter the challenges related with draconian disaster.

To address the COVID-19 crisis and assist the construction industry in improving their safety practices until the discovery of the vaccine, a micro-scale analysis of construction safety practices for Covid-19 has been conducted that could be helpful for construction practitioners to overcome the difficulties that occur during on-site construction projects. These bold steps regarding the safety practices to mitigate the impact of COVID-19 could help cover the major aspects of the construction process. Apart from the consequences, this study may help to curb the impacts of the present crisis. Further, a general assessment regarding the safety practices in the construction sector could assist practitioners, developers, and contractors in preparing for future pandemic outbreaks incidents. It also supports informed decision making from the perspective of ethical and social values. The findings of this novel study may help the construction sector as well as other industries to fight against the pandemic and other disasters also assist them to maintain safety measures and improve work efficiency in construction industry. The findings of this study may help industries to combat with future outbreaks.

This Study consists of several sections. Section 2 discusses the literature review. Section 3 explores the research methodology. Section 4 presents the proposed framework for crisis management in the construction industry and section 5 contains recommendations, suggestions, and policy implications of the study. The Last section discusses the conclusion of the study.

\section{LITERATURE REVIEW}

\subsection{COVID-19, the World's economy and industries}

The pandemic of COVID-19 forced different nations to implement lockdown policy to eradicate the adverse impact on community and economy but it also caused to slow down the world economic growth, ban on travel, unemployment, and restrictions on international trade. The crisis of COVID-19 was considered the World crisis after March 20, 2020. Different world organizations have estimated that this pandemic will have a bad impact on world GDP growth (Economic Outlook, 2020). According to Asian development bank reports, it has been predicted that global GDP may suffer up to $4.8 \%$ due to the COVID-19 outbreak (Park et al., 2020). Also, it may impact on decreasing international foreign direct investment from $6 \%$ to 15\% (United Nations Conference on Trade and Development, 2020). Hevia and Neumeyer (2020) identified that in another report of United Nations Conference on Trade and Development (UNCTAD) to overcome the global economy, international stakeholders require a 2500 billion US dollar relief. So, based on this statistical data, the footprint of this global crisis will be more dangerous than the crisis of 2008 (United Nations Conference on Trade and Development, 2020). It has been assumed that approximately 25 million people will be fired from their jobs in the era of this pandemic, which would be a loss of 3400 million US dollars (Ordonez, 2020). According to the recent reports of the international labor organization (ILO), global lockdown policies, creating bad impact on international employees, which may lead to the loss of more than $80 \%$ workers' job across the world (International Labour Organization, 2020b). Bhuiyan et al. (2020) elaborated that more than three million people may lose jobs in the US only, this critical situation could impact in other continents with same statistics. The adverse impact of COVID-19 in the sector of construction, manufacturing, small medium enterprise and automobile industry could be high, but on defense industry, educational institutes and social work activities could be low (Hyder, 2020).

Due to the severe outbreak of COVID-19 from the start of 2020, industries are suffering from uncertain conditions (Hao et al., 2020). The coronavirus disease impacted the national economies, and different industries are facing different critical issues in the sense of losses. 
Many industries are facing significant problems like shrinkage of demand, distractions in goods supply, the shutdown of trade, the stoppage of import and export, and unavailability of raw material because of worldwide lockdown (Bartik et al., 2020). In the last four decades; various disasters had drastically caused to destroy the economy and growth of different industries. These are including the draconian flood of Holland in 1953, the severe earthquake of Pakistan in 2005, an extreme tsunami of Indonesia in 2004, and hurricane Harvey 2017, respectively (Beardsley and McQuinn, 2009; Rathore et al., 2008, Eggers, 2020). These disasters affected the global society, the economy, and different industries and caused threat the business continuity. Shafi et al. (2020) identified that the crisis of the earthquake, COVID19 outbreak, and tsunami badly stuck different business and manufacturing industries. The severe earthquake of Turkey in 1999 led to damage to the 4.5 billion US dollar investment of small-medium enterprise industries. Also, draconian flood in Thailand cause to loss of 0.5 million enterprise firms, along with 2500000 people lose their jobs (Asgary et al., 2020).

COVID-19 has exaggerated all types of industries across the world; a chemical organization has estimated that the chemical industry may lose 1.2 percent of its global production in this pandemic situation, which is worse than the financial crisis of 2008 (Nicola et al., 2020b). Nicola et al. (2020b) found that a multinational chemical company suspends its activities regarding the upgrading of chemical production because of the pandemic in China. The educational sector is also affected by the outbreak of COVID-19; more than 150 countries-imposed restrictions on educational facilities. United Nations Educational, Scientific and Cultural Organization (UNESCO) predicted that the COVID-19 outbreak adversely influenced more than 800 million learners (Nicola et al., 2020a). To overcome the financial crisis in the epidemic, the UK government provided 330 billion pounds of funds for the business industry; additionally, 20 billion pounds are announced to assist the small-medium enterprise (Nicola et al., 2020b). The tourism industry is also affected by the consequences of COVID-19 because it has been identified that Marriott international is furloughing approximately 174000 workers across the world (Bomey, 2020). Hilton international also announced to borrow the 1.75 billion loan from financial institutes to survive and avoid the uncertain conditions of the global pandemic (Schaal, 2020). Furthermore, the US motel industry requested the US government to grant 150 billion US dollars for survival and 100 billion US dollars for the tourism industry. The global tourism organizations predicted that more than 45 million people are engaged with tourism industry jobs are at stake because of the COVID-19 outbreak (European Travel Commission, 2020). Many tourism organizations have contacted their governments to provide loans to overcome the critical issue that happens in the tourism industry in the worse situation of the corona virus (Gaál, 2020). The Vietnam tourism industry plays an important role in economic growth, but unfortunately, in the first semester of 2020, Vietnam loses 50 percent of its visitors because of COVID-19 (Veitnam Times, 2020). Furthermore, Vietnam may lose 2.3 billion US dollars in the first semester of 2020 , and if the outbreak remains until the end of the second semester of 2020, it might reach up to 5billion dollars loss. The Philippine government is also predicting fallen their GDP up to 0.7 because of the coronavirus (Duddu, 2020).

The outbreak of COVID-19 also affects the agriculture industry, i.e., because of the COVID19 crisis, the production of pesticides declined sharply, which lead to a create shortage of food across the world (Barichello, 2020). Schmidhuber et al. (2020) elaborated that due to restrictions on trade, closure of borders, and delaying in shipping cause to raise the prices of agricultural products. In the middle of the current year, it has been reported that the business of agriculture products was fallen sharply to $75 \%$ from the start of the epidemic (Siche, 2020). A ban on the transportation of food from one place to another place may restrict traders from accessing their actual destination, which may cause waste foodstuff especially perishable goods such as fresh fruits (International Labour Organization, 2020a).

COVID-19 affects the manufacturing industry all over the world. Manufacturing organizations such as automobiles, Samsung electronics, and mechanical parts corporations decided to move their operations towards the countries with less COVID-19 epidemic. The 
purpose of moving the production operations from one place to another is to lessen the potential influence of the COVID-19 outbreak (Markets, 2020). Additionally, Vietnam shifted its smartphone manufacturing operations in South Korea, where the effect of this severe disease is less.

Despite the change in world's economy, negative effects of COVID-19 on all industries, some innovative technologies e.g., industry 4.0 technologies, block chain, artificial intelligence, and big data analytics could enhance performance of construction supply chain. Recent literature describes that implementation of the industry 4.0 technologies is higher in developed nations (Brunheroto et al., 2021). Adoption of industry 4.0 technologies brings significant improvements in construction process (Frazzon et al., 2019). A recent study explored the relationship between agricultural product suppliers and urban residents in financing systems, based on the evolutionary game model (Yu and Rehman Khan, 2021). The circular economy approach in supply chain management offers environmental as well as economic benefits to the organizations (Cazeri et al., 2017). In the industry 4.0 era, there is an emphasis on technology in every field, and block chain technology is found vital to play a positive role in the circular economy (Rehman Khan et al., 2021).

An outbreak of COVID-19 has disrupted the supply chain of construction projects which provided insights to government, businesses, and policymakers to proactively prepare and plan alteration policies (Yu et al., 2021). A study shows that more focus on industry 4.0 resulted in a lack of research regarding supply chain digitalization (Vafaei et al., 2019). To mitigate the obstacles during the pandemic, effective application of knowledge management is more reliable (Pinto, 2020).

\subsection{Drastic effect of COVID-19 on the construction industry}

The construction sector plays a vital role in empowering the economy and development of any country across the world. The construction industry provides a smooth mechanism to develop job opportunities for billions of inexperienced and experienced workers worldwide. The construction industry helps to enhance economic growth through direct and indirect ways (Dlamini, 2012). The construction sector is facing massive uncertainty because of drastic pandemic. Contractors and developers interact with each other through zoom and other applications to eliminate the risk of COVID-19 (Pickford, 2020). Worldwide, millions of workers jobs are at risk due to COVID-19. According to the international monetary fund (IMF) in the current pandemic situation, the world GDP will decrease by up to 3\% compared with 2019.

Further, drastic effect of COVID-19 on construction sector of different economies in the world is shown in Table 1.

\section{RESEARCH METHODOLOGY}

This study is based on exploratory and conceptual finding in which the data is presented to visualize the impact of pandemic on construction industry also a framework is proposed to combat with future pandemics. There are different research techniques that can be utilized to explore the basic purpose of research but the existing study has been presented in an exploratory direction also due to lack of Covid-19 clear situation, the qualitative technique was adopted to achieve the objectives of study. Pappas et al. (2019) adopted an exploratory method to sort out the factors of Modulation of Egg Metallome with Flavonoids. Asdiou and Mokhtari (2019) used an exploratory framework to find the directions of corporate social responsibility and explore the support of encouragement of organization to use the CSR. Some scholars prefer to adopt the expert based studies such as (Iqbal et al., 2021a; 2021b) adopted ISM-MICMAC quantitative technique to identify the barriers and strategies towards the adoption of energy efficient technologies in construction industry. Hussain et al. (2019) describes that adoption of research methodology to classify the best findings for study is a significant task. Umar (2022) identified that two elements including specific research questions and investigation of specific topic while reviewing the research technique are very important 
for researchers to encounter the research methodologies. Jobber et al. (1991) identified that supporting of one methodology on the basis of some advantages is totally wrong because every methodology has some pros and cons. Many of researchers suggest both approaches such as qualitative approach and quantitative approach to examine the findings of research studies. Therefore, according to the current pandemic situation and topic of research a qualitative approach was adopted for this study as compare with quantitative research approach.

Due to lock down imposition across the globe, 35 experts of construction industry were approached though emails. After two reminders 23 experts were willing to provide their response regarding the impacts, safety measures and crisis management in construction sector through SKYPE (list of experts is shown in Table 2). The existing literature recommend that in the era of pandemic and draconian situation online interviews are suitable for study.

The experts that were approached to get their response regarding the existing study were on key posts in their organizations along with having sound experience in their fields. As the sample size was 23 which is suitable to conduct an exploratory and qualitative research because Mason (2010) identified that the sample size for achieving objective of a qualitative study should be at least twenty. Further Umar (2020) adopted a qualitative methodology in which the respondents of the study were twenty which is enough to conduct an exploratory research.

The respondents of the existing research were firstly brief about the basic purpose of the study. Each respondent was asked to pinpoint the significant impact of COVID-19 on construction industry then suggest best safety practices along with crisis management framework to encounter the challenges in recent era. The data during the interview was gather in a direction in which the content analysis approach can be implemented easily. Content analysis consist of coding the complete text/script. It helps to investigate the wide range of different studies.

\section{RESULTS \& DISCUSSION}

\subsection{COVID-19 and redesigning construction practices}

As the pandemic of coronavirus feasts globally, many industries have suspended their operations, but the construction industry has continued their operations in some construction projects. For workers' and professionals' safety, construction practitioners need to enhance safety practices from the exposure of COVID-19. Responsible construction practitioners are keen to prove they can work safely and avert the coronavirus to support workers and their families in the critical situations of this pandemic. According to the Bureau of Labor Statistics, the construction industry employs almost 7,505,000 people globally.

To ensure the best practices in construction projects in the era of COVID-19, the practitioners should formulate and implement Site-Specific health and safety plans for workers. Some precautionary measures could be beneficial for workers to prevent COVID-19 and future crisis which are given below:

\subsubsection{Keep Physical Distancing}

The droplets of coronavirus can travel almost 9 meters from the affected person after the emission of cough and sneeze (Ramesh et al., 2020). Rothan and Byrareddy (2020) explain that the droplets of corona patients are also spread by talking; meanwhile, the virus can live for many hours on the surface such as on equipment, counters, and door handles. It has also been identified that a person who has a virus, but symptoms are not displaying can be a source to spread the virus.

These critical facts help undercover the significant importance of physical distancing among workers to control the virus infection. The construction practitioners should make sure 
the enforcement of physical distance protocol at the construction site. Construction workers should reach on site, with buses at half load to ensure safer social distancing. Each worker must score a temperature reading of under 37-degree centigrade to be allowed on site.

\subsubsection{One-worker, one-task policy}

COVID-19 prevention activities should be incorporated into overall work and task hazard assessments. All construction firms should identify whether each task can be performed by a single employee, and if not, then extraordinary personal protective measures should adopt to ensure the safety of all workers. Images of hazard analysis should be taken through smartphones and sent via SMS because this proactive approach could be beneficial to familiarize with serious injury and fatality program.

\subsubsection{Monitoring through advanced technology}

Trained professionals should be hired to monitor social distancing. On-site construction should be monitor through CCTV cameras and Drones. Construction safety software like Vinnie Al Interface that analyze the performance of employees regarding suitable distancing between workers should be implemented in construction projects in the present situation of COVID-19 pandemic.

\subsubsection{Scheduling}

Work activities should be divided into different shifts that could help decrease the workload and reduce the number of workers on site. To reduce the interactions among workers, break time should be rescheduled and non-essential employees are allowed to work at home.

\subsubsection{Site logistics and control}

Access control is a significant factor. There should be a controlled and limited number of visitors and workers on-site to maintain a sustainable environment regarding the prevention of the virus. Entrance doors, parking areas should be controlled through sensors and remote control. To ensure the safety of workers and visitors, there should be thermal imagery cameras to analyze the body temperature.

Table 1: impact on the construction industry in different countries due to COVID-19

\begin{tabular}{|c|c|c|c|c|c|c|c|}
\hline Country & Population & $\begin{array}{c}\text { Deaths/100/ } \\
\text { K } \\
\text { Population }\end{array}$ & $\begin{array}{c}\text { Lockdown } \\
\text { period }\end{array}$ & $\begin{array}{l}\text { Lockdow } \\
\text { n level }\end{array}$ & $\begin{array}{c}\text { Estimated } \\
\text { loss (\$) }\end{array}$ & $\begin{array}{c}\text { Impact on } \\
\text { construction } \\
\text { industry/government } \\
\text { response }\end{array}$ & Ref. \\
\hline UK & 66.65 million & 65.68 & $\begin{array}{l}\text { 24-March- } \\
2020 \text { to 4- } \\
\text { July-2020 }\end{array}$ & $\begin{array}{l}\text { National } \\
\text { level }\end{array}$ & $\begin{array}{c}3.9 \text { million } \\
\text { per day }\end{array}$ & $\begin{array}{l}\text { In the first quarter of } \\
2020 \text {, the construction } \\
\text { sector of UK lost } 2.1 \% \\
\text { towards the contribution } \\
\text { to GDP and fell 5.9\% in } \\
\text { March due to COVID-19 } \\
\text { as well as output of } \\
\text { construction will shrink } \\
25 \% \text { in } 2020 \text {.The UK } \\
\text { government announced } \\
\text { designing a policy that } \\
\text { can support construction } \\
\text { sector to contribute to } \\
\text { the national economy in } \\
\text { the draconian situation } \\
\text { of COVID-19. }\end{array}$ & $\begin{array}{c}\text { (Preston, 2020; } \\
\text { IbisWorld, } \\
\text { 2020; } \\
\text { Construction } \\
\text { News, 2020) } \\
\end{array}$ \\
\hline
\end{tabular}




\begin{tabular}{|c|c|c|c|c|c|c|c|}
\hline Country & Population & $\begin{array}{c}\text { Deaths } / 100 / \\
\mathrm{K} \\
\text { Population }\end{array}$ & $\begin{array}{l}\text { Lockdown } \\
\text { period }\end{array}$ & $\begin{array}{c}\text { Lockdow } \\
\text { n level }\end{array}$ & $\begin{array}{c}\text { Estimated } \\
\text { loss (\$) }\end{array}$ & $\begin{array}{c}\text { Impact on } \\
\text { construction } \\
\text { industry/government } \\
\text { response }\end{array}$ & Ref. \\
\hline Australia & 25.4 million & 3.62 & $\begin{array}{l}\text { 23-March- } \\
2020 \text { to } \\
\text { (to be } \\
\text { announced) }\end{array}$ & $\begin{array}{c}\text { National } \\
\text { level }\end{array}$ & 12 billion & $\begin{array}{l}76500 \text { workers lost } \\
\text { their jobs from March- } \\
\text { May that is accounted } \\
\text { for } 182000 \text { dollars' } \\
\text { worth of annual work }\end{array}$ & $\begin{array}{l}\text { (Senthilkumar } \\
\text { et al., 2020; } \\
\text { Bleby, 2020) }\end{array}$ \\
\hline $\begin{array}{c}\text { New } \\
\text { Zealand }\end{array}$ & 4.886 million & 0.51 & $\begin{array}{l}\text { 26-March- } \\
2020 \text { to (to } \\
\text { be } \\
\text { announced) }\end{array}$ & $\begin{array}{l}\text { National } \\
\text { level }\end{array}$ & $\begin{array}{l}245 \\
\text { million/mon } \\
\text { th }\end{array}$ & $\begin{array}{l}\text { The construction } \\
\text { industry suspended } \\
\text { operations for the sake } \\
\text { of workers' health and } \\
\text { safety due to COVID- } \\
\text { 19. The government } \\
\text { announce one-billion- } \\
\text { dollar package to relief } \\
\text { the construction sector } \\
\text { and boost the } \\
\text { economy }\end{array}$ & $\begin{array}{l}\text { (Day, 2020; } \\
\text { Desk, 2020b) }\end{array}$ \\
\hline India & 1.353 billion & 8.35 & $\begin{array}{l}\text { 25-March- } \\
2020 \text { to 03- } \\
\text { May-2020 } \\
\text { (Senthilkumar } \\
\quad \text { et al.) }\end{array}$ & $\begin{array}{l}\text { National } \\
\text { level }\end{array}$ & $\begin{array}{l}4.1 \\
\text { million/per } \\
\text { day }\end{array}$ & $\begin{array}{l}\text { Due to pandemic } \\
\text { outbreak, investment } \\
\text { in construction } \\
\text { projects has been } \\
\text { reduced up to percent } \\
\text { and up to } 34 \text { percent } \\
\text { labor fired from work }\end{array}$ & $\begin{array}{l}\text { (Moneycontrol } \\
\text { News, 2020; } \\
\text { Desk, 2020a) }\end{array}$ \\
\hline Nepal & 28.09 million & 2.59 & $\begin{array}{l}\text { 24-March- } \\
2020 \text { to } 21- \\
\text { July-2020 }\end{array}$ & $\begin{array}{l}\text { National } \\
\text { level }\end{array}$ & 509 million & $\begin{array}{l}\text { Most of the } \\
\text { Contractors lost their } \\
\text { revenue due to } \\
\text { employees' salary and } \\
\text { site management }\end{array}$ & $\begin{array}{c}\text { (Ramesh et al., } \\
2020 ; \\
\text { Ramesh et al., } \\
2020)\end{array}$ \\
\hline Maldives & 0.56 million & 6.98 & $\begin{array}{c}\text { 15-April-2020 } \\
\text { to } 28-M a y- \\
2020\end{array}$ & $\begin{array}{l}\text { National } \\
\text { level }\end{array}$ & 40 million & $\begin{array}{l}\text { More than seven } \\
\text { thousand construction } \\
\text { workers suffer from } \\
\text { the pandemic } \\
\text { situation; also, } \\
\text { construction industry } \\
\text { bearing huge loss due } \\
\text { to delay in } \\
\text { construction projects. }\end{array}$ & $\begin{array}{l}\text { (Huaxia, 2020; } \\
\text { Gardaworld, } \\
\text { 2020; Xinhua, } \\
\text { 2020) }\end{array}$ \\
\hline
\end{tabular}

Practitioners required a planned and straight forward strategic policy to deliver the goods and other miscellaneous stuff for workers such as specific areas should be fixed to deliver parcels for workers, lines can be painted to fix the areas for employees, hurdles could be placed to isolated the employees from delivery points, trash box can be fixed on specific location where it can be transferred from site, to avoid the socialization in this worse situation delivery men should remain in vehicles and wear gloves when handover the parcels of workers.

The construction site should be assessed by concerned authorities to ensure the physical distancing among workers. Fine policy should be imposed on those workers who are careless and violate the safety policies of the organization. Food market areas should be shut down to maintain social distance. Coffee points, water dispensers, and air conditions should be removed from break areas.

\subsubsection{Administrative action and policies}

To ensure the safety practices and control the spread of COVID-19 on construction sites, the collaboration and motivation of construction practitioners are essential at all levels. Observation of employees on site is a very significant factor and more capital is required to buy the additional safety technologies to protect the employees and their families. Financial 
institutes and government could help construction organizations through the provision of loans on zero interest with a long payback period.

Table 2. Demographics and Respondents profile

\begin{tabular}{cccccc}
\hline NO & Code & Education & Designation & Experience & Size of firm \\
\hline 1 & C1 & Contractor & Director & 27 & 200 \\
\hline 2 & C2 & Contractor & Director & 19 & 170 \\
\hline 3 & C3 & Contractor & Director & 21 & 300 \\
\hline 4 & C4 & Contractor & General Manager & 18 & 500 \\
\hline 5 & C5 & Contractor & General Manager & 11 & 200 \\
\hline 6 & CE1 & Civil Engineer & Superintendent Officer & 7 & 700 \\
\hline 7 & CE2 & Civil Engineer & Associate Engineer & 11 & 350 \\
\hline 8 & CE3 & Civil Engineer & Associate Engineer & 9 & 350 \\
\hline 9 & CT1 & Consultant & General Manager & 25 & 20 \\
\hline 10 & CT2 & Consultant & General Manager & 23 & 35 \\
\hline 11 & CT3 & Consultant & Chief Executive Officer & 14 & 23 \\
\hline 12 & CT4 & Consultant & Director & 19 & 50 \\
\hline 13 & CT5 & Consultant & Director & 11 & 15 \\
\hline 14 & AC1 & Architect & Project manager & 7 & 13 \\
\hline 15 & AC2 & Architect & Project architect & 11 & 140 \\
\hline 16 & AC3 & Architect & Surveyor & 5 & 90 \\
\hline 17 & AC4 & Architect & Assistant director & 7 & 200 \\
\hline 18 & SE1 & Safety Engineer & Director & 10 & 430 \\
\hline 19 & SE2 & Safety Engineer & Director & 13 & 300 \\
\hline 20 & SE3 & Safety Engineer & Quality officer & 8 & 280 \\
\hline 21 & AC1 & Academician & Professor & 17 & 5000 \\
\hline 22 & AC2 & Academician & Associate professor & 15 & 5000 \\
\hline 23 & AC3 & Academician & Associate professor & 15 & 3500 \\
\hline & & & & & \\
\hline
\end{tabular}

The top leadership of construction projects needs to adopt zero-tolerance policy to impose safety measures during construction. Sick employees should be isolated and selfquarantine for two weeks and top management should aware their workers regarding the symptoms of COVID-19 such as cough, sneezing, fever, and difficulty to take breathe. A form related to COVID-19 should be developed where a worker can fill all the required information regarding symptoms of the virus.

An online application should be introduced to help workers submit their daily health report on that application. In that application, there should be following questions for employees.

- Do you have any symptoms such as dry cough, fever, and fatigue?

- Were you in close contact with novel coronavirus patients or suspected patients during last 14 days?

- Have you traveled abroad?

- Are you able to contact higher management if you have any problem?

- Is your body temperature normal?

- Can you promise to abide by the regulations of the organization?

To ensure the safety of employees make sure to assign a nurse on-site and implement twenty four hours nurse screening triage to be used by all employees. Suppose the recruitment of nurse is not possible on-site then a trained worker should be assigned to monitor the temperature, and illness of employees. Sanitizing gate should be fixed at the entrance gate on-site.

In this critical situation it is essential to concentrate on the mental health of employees by asking them how they and their families are adopting precautionary measures. Setting a 
good culture of safety practices to preserve employees from COVID-19 will help organization to enhance awareness and compliance.

\subsubsection{On-site Worker education and tutorials}

Some organizations assumed that their employees are well informed regarding the realities of virus disease. The most significant challenge for government and health officials is to prevent misleading information of COVID-19 on social media. Furthermore, to enforce the COVID-19 policies for workers and other construction practitioners, concerned authorities should discuss standard of policies SOPs i.e., how to manage social distancing among employees and how to report if an employee or their colleague have symptoms of COVID-19 and when employees can go back for work. Educating employees' top leadership should make a video message about COVID-19 prevention and upload on social media, as well as distribute it to employees. Posters should be placed on the entrance of site like "stay home when you are sick" and "no mask no entry." Daily updates of COVID-19 patients should be provided on social media and employees chat groups. For the convenience of employees, on-site tutorials and explanation materials should be posted in different languages.

The workers should follow the regulations set by government and organization to ensure the social distancing during shopping, exercising and other important activities.

\subsubsection{Engineering controls}

According to the nature of worksite, and a variety of engineering controls could be used to enhance the activity of social distancing and limit employees' exposure i.e., ventilation equipment can be used for those workers who work in close quarters. Provision of supplementary stair towers, elevators will also help to limit close contacts. Use of plastic sheets could help to isolate employee in dusty operations when the dust cannot be eliminated through other engineering controls. Water cannon could be beneficial to stop the dust on site. Installation of sticky mats and shoe sanitation tubs on exit and entry points assist in controlling the COVID-19.

\subsubsection{Sanitation and hygiene}

Sanitation and hygiene are important factors to prevent COVID-19. During the project selection, sanitation and hygiene schedule are essential such as an item that could be touched like door handles, locks, and keys should be prioritized. Cleaning protocols should be clearly addressed with frequent cleaning of keyboards, computers, doors, pens etc. Before delivering any parcel on-site, it should be clean and vehicle should be sanitized before entering in the construction site. UV sanitation and fog sanitation are also used to sanitize the goods. The construction practitioners should ensure the availability of hand sanitizer and handwashing soaps on site. Toilets of construction site should be regularly clean and disposable toilet paper should be used as seat covers instead of touching the toilet directly. Use of personal and disposable glasses is suitable on construction site.

\subsubsection{Personal protective equipment (PPEs)}

Imposition of PPEs regarding safety measures is a critical element in every industry. In worse situation of COVID-19 following the personal protection is essential to protect the employees for becoming infected by colleagues. Employees should wear gloves, masks, gaiters, glasses, and face shields all the time on site. All the construction practitioners must follow recommendations of manufacturer regarding the sanitization and decontamination of PPEs and clothing before using them.

\subsubsection{Tools and equipment}

As the virus remain active in droplets for a long time so the tools which are used during work and shared with each other by workers must be eliminated and cleaned regularly. Before 
using any equipment first, it should be disinfected and the employees who use this equipment should wash and sanitize their hands to prevent virus spread. For the safety of employees, used tools should be left for three days after cleaning with a diluted bleach solution.

Lastly, Figure 1 shows a comprehensive version of COVID-19 based security measures for construction sector.

\subsection{Proposed framework for crises management in construction industry}

In the drastic situation of COVID-19 the significant factor is that either the construction sector should move towards the new future directions or adopt a traditional routine of work. Three steps of significant factors are suggested to tackle this issue.

Stage1. in the era of pandemic situations to survive in the market, construction organizations must secure their capital not to be a defaulter. Also, the organizations must prepare for any change that may occur in the future. Early initiative for the sake of business survival could protect construction sector from huge loss. Prediction of risk identification in the early stages of any project may lead to avoiding the adverse consequences. However, in an unprecedented condition of COVID-19, the government and financial institutes must provide funds and subsidies for construction industry that could reduce the risk of default and insist on enhancing the business operations.

Stage2. As construction industry is a major player towards the contribution of economic growth so the construction sector must adopt the innovative and digitalized approaches to enhance the business operations in a smooth way as well as companies must formulate significant strategies and recruit flexible workforces that could be beneficial to encounter the impact of COVID-19 and be able to take advantage of the resulting opportunities. To enhance the revenue of an organization, stakeholders must invest in merger and acquisition activities that could increase the profit of construction industry. The purpose of taking such types of steps must be clear and powerful that could ensure the excellent future of organizations.

Stage3. Lastly, to remain in the normal situation, the stakeholders like builders, contractors etc. must divert their attention towards the green transformation. Companies should set their targets; increase sales through social media promotions, print media, billboards, and electronic media. Key players must invest in the research and development activities that could enhance the profitability of construction companies. Operations of projects must be a move towards the innovative way of building information modeling (BIM) instead of traditional approaches. The latest business models, such as BIM could play an important to improve the efficiency of the projects. Through the optimization of asset management and diversification of material suppliers, the construction industry can achieve their desired goals effectively for the long-term future.

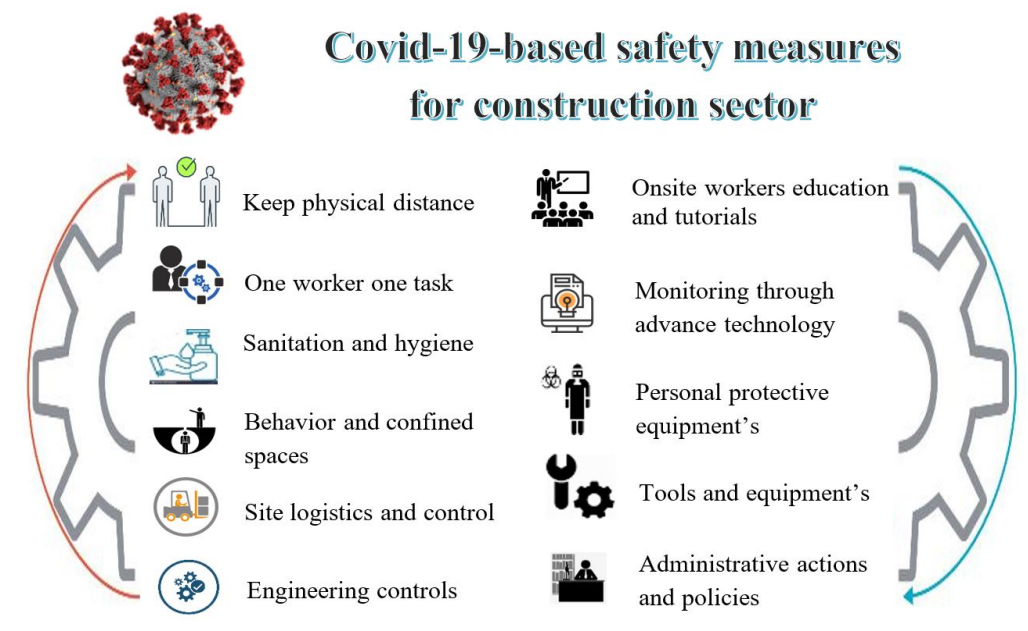

Figure 1. COVID-19 based safety measures for construction sector Source: Adapted from Roland Berger (Schober, 2020). 
Lastly, a three-step approach of crisis management framework in accordance to COVID19 is shown in Figure 2, which provides further insights about different stages.

\subsection{Discussion}

Whenever there is a disaster across the world, it brings long-lasting adverse impact on society and economic conditions. However, the current COVID-19 outbreak is one of them. Different previous studies highlighted the negative impacts of pandemics and recommended how to overcome such draconian outbreaks. Yoldascan et al. (2010) identified that pandemic of influenza badly affect the economy of turkey, the estimated loss of Turkish economy was almost 2.6 billion US dollars. Meltzer et al. (1999) defined that disease of influenza disturbed the economy of United states and total cost of economic loss was 71.3 to 166.5 billion US dollars. Similarly, in $21^{\text {st }}$ century the COVID-19 is a major disaster which disturbed the world economy. Worse impact of coronavirus has stuck all economic and social activities in the world. However, this disaster is still going on, so it is significant to take some initiatives through which the adverse impact of COVID-19 could be minimize on business operations and social activities. Different researchers proposed safety practices in construction sectors such as Vitharana et al. (2015) draw attention of contractors and developers towards the adoption of safety practices.

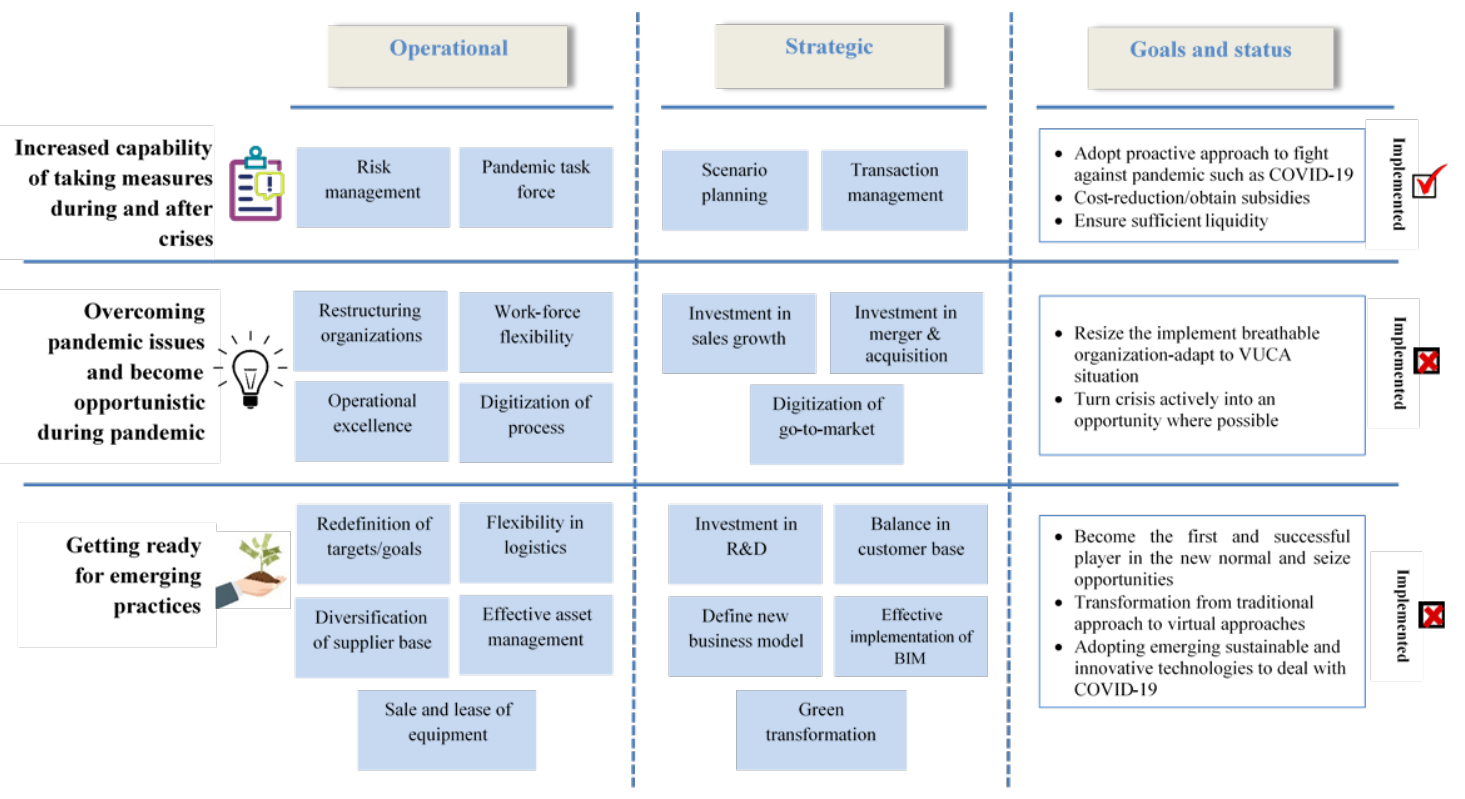

Figure 2: Proposed framework for crises management in construction sector. Source: Adapted from Roland Berger (Schober, 2020).

Similarly Sahin et al. (2015) suggested an innovative crisis management model for construction sector but these steps were taken in the perspective of routine activities therefore, in this study safety practices and crisis management framework is suggested in the era of existing pandemic situation.

\section{RECOMMENDATIONS AND SUGGESTIONS AND POLICY IMPLICATIONS OF THE STUDY}

Due to an unprecedented situation, the construction industry has been hit badly across the world. In this worse situation, nobody has an idea how COVID-19 could be controlled, but with the passage of time bold step should be taken by governments and concerned stakeholder to eliminate the worse situation. These bold steps may reduce the efficiency of running construction projects, but it could help to run the construction sector in a better and healthy environment. Some recommendations could help contractors, government, 
policymakers and other concerned authorities to manage the construction work in a smooth and better way for the safety of all stakeholders that are involved in construction work. These recommendations may help to overcome future outbreaks.

This research has substantial implications for the construction sector, government, and policymakers. This study suggests that, for smooth operations of the construction industry's supply chain during COVID-19, the supply chain needs to alter into a resilient supply chain. As advanced technology plays a vital role in supply chain operations, especially in COVID-19, artificial intelligence, machine learning, 5-G technology, and block chain will calibrate supply with more realistic forecast demand (Schatteman et al., 2020). Project contractors can improve their work performance through the enforcement of strict protective measures of COVID-19. This study could help policy makers to adopt such type of safety policies in other industries. Through the suggested framework of crisis management project managers can forecast future planning to minimize the project loss. Supportive mechanism of protective measures from governmental and other concerned authorities can encourage all industrial sectors to adopt smooth safety practices against any disaster.

\section{CONCLUSION}

COVID-19 outbreak brings adverse impact on public health, economic growth, and social life, including the construction industry across the world. The nationwide lockdown in various countries was adopted to reduce the pace of COVID-19 that cause to impact the business operations, manufacturing, construction, aviation and transport sector which resulted in changing the work pattern of the organizations. Due to change in work pattern of different organizations, construction projects have been delayed, workforce capacity has been reduced and economic growth falls rapidly. To overcome the critical issues and crisis in construction industry, a crisis management framework and safety health practices for construction employees has been recommended. The construction sector can play a vital role by adopting safety practices in the construction process. The construction industry must work hard to eliminate the adverse impact of COVID-19 by minimizing the workforce capacity on-site and enhancing the off-site work to avoid uncertain conditions. The contractors should pay attention to the legal issue that could be faced in the future due to delay in projects and uncontrollable prices of material. However, the projects that are still in the process must be given attention through the better safety practices for employees that could help to overcome the crisis in the worse situation of COVID-19. The important safety practices are including; maintain the social distancing among employees, one worker one task, monitoring through innovative technologies, and disinfecting the tools and equipment after work. The finding of this study is significant for construction sector, government and policymakers to understand the adverse impact of the unforeseen and uncontrolled pandemic on construction industry.

This study has certain limitations e.g. the availability of data regarding construction sector was limited especially about small countries whose economies are not fully documented and construction sector is not regulated. The evaluation and assessment made in this study were generally subjective and it cannot be generalized to other sectors. This work could insist on enhancing the work plan for the future to encounter the uncertain circumstances for construction industry. Future studies could examine the implementation of the proposed framework set out in this study to further extend the analysis. Subsectors of the building industry, such as residential projects, industrial projects, mega-public sector projects, may be analyzed separately in order to define their individual sector COVID-19 prevention practices. Systematic reviews can also be useful in finding the insights into construction industry preventive activities. Survey based study can also be helpful in getting the specific data from targeted population.

\section{REFERENCES}

Afkhamiaghd, A. and Elwakil, E. (2020), "Preliminary modeling of Coronavirus (COVID-19) spread in construction industry", Journal of Emergency Management (Weston, Mass.), Vol. 18, pp. 9-17. 
Alsharef, A., Banerjee, S., Uddin, S. et al. (2021), "Early Impacts of the COVID-19 Pandemic on the United States Construction Industry", International Journal of Environmental Research and Public Health, Vol. 18, pp. 1559.

Asdiou, A. and Mokhtari, B. (2019), "The indicators of the corporate social responsibility: a search for efficiency or a concern for legitimacy towards stakeholders? A proposed explanatory model", International Journal of Service Science, Management, Engineering, and Technology, Vol. 10, pp. 62-76.

Asgary, A., Ozdemir, A.I. and Özyürek, H. (2020), "Small and medium enterprises and global risks: evidence from manufacturing SMEs in Turkey", International Journal of Disaster Risk Science, Vol. 11, pp. 59-73.

Barichello, R. (2020). "The COVID-19 pandemic: anticipating its effects on Canada's agricultural trade", Canadian Journal of Agricultural Economics/Revue canadienne d'agroeconomie, Vol. 68, No. 2, pp. 21924.

Bartik, A.W., Bertrand, M., Cullen, Z.B. et al. (2020). How are small businesses adjusting to covid-19? early evidence from a survey. National Bureau of Economic Research.

Beardsley, K. and McQuinn, B. (2009), "Rebel groups as predatory organizations: The political effects of the 2004 tsunami in Indonesia and Sri Lanka", The Journal of Conflict Resolution, Vol. 53, pp. 624-45.

Bhuiyan, A. I., Sakib, N., Pakpour, A.H., et al. (2020). "COVID-19-related suicides in Bangladesh due to lockdown and economic factors: case study evidence from media reports", International Journal of Mental Health and Addiction. Ahead of print. PMID: 32427168.

Bleby, M. (2020, March 21), “Construction sheds $\$ 14$ billion since March”, Financial Review.

Bomey, N. (2020, March 17), "Marriott to furlough tens of thousands of workers as coronavirus batters hotel industry", USA Today.

Brunheroto, P.H., Tomanek, D.P. and Deschamps, F. (2021), "Implications of Industry 4.0 to companies' performance: a comparison between Brazil and Germany", Brazilian Journal of Operations \& Production Management, Vol. 18, pp. 1-10.

Bsisu, K.A.-D. (2020), "The impact of COVID-19 pandemic on Jordanian civil engineers and construction industry", International Journal of Engineering Research \& Technology (Ahmedabad), Vol. 13, pp. 828-30.

Cazeri, G.T., Anholon, R., Ordoñez, R. et al. (2017), "Performance measurement of green supply chain management: a literature review and gaps for further research", Brazilian Journal of Operations \& Production Management, Vol. 14, pp. 60-72.

Construction News. (2020), "Virus costs UK construction more than $£ 300 m$ a day", Construction News.

Day, L. (2020, April 17), Multimillion-dollar losses to construction and manufacturing from lockdown. Star News.

Desk, W. (2020a, May 9), “COVID-19 pandemic is likely to reduce investment in construction related projects: KPMG", The Hindu.

Desk, W. (2020b), "First days of New Zealand lockdown were unlawful, High Court finds", The Sydney Morning.

Dlamini, S. (2012), "Relationship of construction sector to economic growth", in International Congress on Construction Management Research, Birmingham City University, Canada, pp. 213-224.

Duddu, P. (2020), “Coronavirus in Philippines: The COVID-19 risk, impact and measures", available at: https://www.pharmaceutical-technology.com/features/coronavirus-affected-countries-philippinesmeasures-impact-tourism-economy/ (accessed 4 August 2020].

Dutta, P., Choi, T.-M., Somani, S. et al. (2020), "Blockchain technology in supply chain operations: applications, challenges and research opportunities", Transportation Research Part E, Logistics and Transportation Review, Vol. 142, pp. 102067.

Economic Outlook. (2020), “World Economic Prospects Monthly (2/2020)”, Economic Outlook, Vol. 44, No. S4, pp. 1-33.

Eggers, F. (2020), "Masters of disasters? Challenges and opportunities for SMEs in times of crisis", Journal of Business Research, Vol. 116, pp. 199-208.

European Travel Commission. (2020, March 17), “European Tourism Sector Demands Urgent Supportive Measures to Reduce Devastating Impact of COVID-19", Today's News.

Frazzon, E.M., Rodriguez, C.M.T., Pereira, M.M. et al. (2019), "Towards supply chain management 4.0", Brazilian Journal of Operations \& Production Management, Vol. 16, pp. 180-91. 
Gaál, B. (2020, March 17), "Tourism alliance demands measures to reduce COVID-19 impact", Budapest Business Journal.

Gamil, Y. and Alhagar, A. (2020), "The impact of pandemic crisis on the survival of construction industry: a case of COVID-19", Mediterranean Journal of Social Sciences, Vol. 11, pp. 122-122.

Gardaworld. (2020), “Maldives: Authorities extend lockdown in Greater Male region to May 28 /update 9", Gardaworld News.

Global Data. (2020). "Global Construction Outlook to 2024 (including Covid-19 Impact Analysis)", available: https://store.globaldata.com/report/gden0019go--global-construction-outlook-to-2024-covid-19impact/ (accessed 23 July 2020).

Hao, F., Xiao, Q. and Chon, K. (2020), "COVID-19 and China's Hotel industry: impacts, a disaster management framework, and post-pandemic agenda", International Journal of Hospitality Management, Vol. 90, pp. 102636.

Hevia, C. and Neumeyer, A. (2020), A Conceptual Framework for Analyzing the Economic Impact of COVID-19 and its Policy Implications, UNDP Latin America and the Caribbean, New York, UNDP LAC COVID-19 Policy Documents Series, No. 1.

Huaxia. (2020, June 6), "Maldives construction industry loses 40 mln USD due to COVID-19", Xinhua News.

Hussain, K., He, Z., Ahmad, N. et al. (2019), "Green, lean, six sigma barriers at a glance: a case from the construction sector of Pakistan", Building and Environment, Vol. 161, pp. 106225.

Hyder, A. (2020), Short Notes on the Economy During the COVID-19 Crisis, Institute of Business Administration Karachi, Paquistão.

IbisWorld. (2020), “COVID-19: UK industry fast facts”, available at: https://www.ibisworld.com/industryinsider/coronavirus-insights/covid-19-uk-industry-fast-facts/ (accessed 1 August 2020).

International Labour Organization - ILO. (2020a), "COVID-19 and the impact on agriculture and food security", available at: https://www.ilo.org/wcmsp5/groups/public/---ed_dialogue/--sector/documents/briefingnote/wcms_742023.pdf (accessed 15 July 2020).

International Labour Organization - ILO. (2020b), "ILO Monitor: COVID-19 and the world of work", available at: https://www.ilo.org/global/topics/coronavirus/impacts-andresponses/WCMS_767028/lang--en/index.htm (accessed 1 August 2020).

Iqbal, M., Ma, J., Ahmad, N. et al. (2021a). “Promoting sustainable construction through energy-efficient technologies: an analysis of promotional strategies using interpretive structural modeling", International Journal of Environmental Science and Technology, pp. 1-24.

Iqbal, M., Ma, J., Ahmad, N. et al. (2021b), "Sustainable construction through energy management practices in developing economies: an analysis of barriers in the construction sector", Environmental Science and Pollution Research International, Ahead of print.

Jobber, D., Mirza, H. and Wee, K.H. (1991), "Incentives and response rates to cross-national business surveys: a logit model analysis", Journal of International Business Studies, Vol. 22, pp. 711-21.

Khan, S. A. R., Jabbour, C. J. C., Mardani, A. et al. (2020), “Supply Chain and Technology Innovation during COVID-19 Outbreak", International Journal of Physical Distribution \& Logistics Management, pp. 1-6.

Markets, R. A. (2020, April 16), "Impact of COVID-19 on the Global Manufacturing Industry, 2020", CISION PR Newswire.

Mason, M. (2010), "Sample size and saturation in PhD studies using qualitative interviews", Forum Qualitative Sozialforschung/Forum: Qualitative Social Research.

Meltzer, M.I., Cox, N.J. and Fukuda, K. (1999), "The economic impact of pandemic influenza in the United States: priorities for intervention", Emerging Infectious Diseases, Vol. 5, pp. 659.

Moneycontrol News. (2020, May 8), “Coronavirus | Construction sector facing daily loss of Rs 30,000 crore; investments in projects to fall 13-30\%: KPMG", Moneycontrol.

Nicola, M., Alsafi, Z., Sohrabi, C. et al. (2020a), "The socio-economic implications of the coronavirus and COVID-19 pandemic: a review", International Journal of Surgery

Nicola, M., Alsafi, Z., Sohrabi, C. et al. (2020b), "The socio-economic implications of the coronavirus pandemic (COVID-19): a review", International journal of surgery (London, England), Vol. 78, pp. 185-93. 
Ogunnusi, M., Hamma-Adama, M., Salman, H. et al. (2020). "COVID-19 pandemic: the effects and prospects in the construction industry", International Journal of Real Estate Studies, Vol. 14, No. 2, pp. 120-8.

Ordonez, J. (2020). "Almost 25 million jobs could be lost worldwide as a result of COVID-19, says ILO", available at: https://www.ilo.org/global/about-the-ilo/newsroom/news/WCMS_738742/lang-en/index.htm (accessed 27 July 2020).

Pappas, A.C., Zoidis, E., Goliomytis, M. et al. (2019), "Elemental Metabolomics: Modulation of egg metallome with flavonoids, an exploratory study", Antioxidants, Vol. 8, No. 9, pp. 361.

Park, C.-Y., Villafuerte, J. and Abiad, A. (2020), “Updated assessment of the potential economic impact of COVID-19", ADB Briefs, No. 133, pp. 1-16.

Pickford, J. (2020, March 20), Coronavirus fears hit UK property market as viewings dry up", Financial Times.

Pinto, C.A.S. (2020), "Knowledge management as a support for supply chain logistics planning in pandemic cases", Brazilian Journal of Operations \& Production Management, Vol. 17, No. 3, pp. e2020970.

Preston, S.S.D. (2020), "Covid-19 recovery plan for the UK construction sector", available at: https://www.fieldfisher.com/en/insights/covid-19-recovery-plan-for-the-uk-construction-sec (accessed 30 July 2020).

Ramesh, N., Siddaiah, A. and Joseph, B. (2020), "Tackling corona virus disease 2019 (COVID 19) in workplaces", Indian Journal of Occupational and Environmental Medicine, Vol. 24, No. 1, pp. 16-8.

Rathore, F.A., Farooq, F., Muzammil, S. et al. (2008), "Spinal cord injury management and rehabilitation: highlights and shortcomings from the 2005 earthquake in Pakistan", Archives of Physical Medicine and Rehabilitation, Vol. 89, No. 3, pp. 579-85.

Rehman Khan, S.A., Yu, Z., Sarwat, S. et al. (2021), “The role of block chain technology in circular economy practices to improve organisational performance", International Journal of Logistics Research and Applications, pp. 1-18.

Rothan, H.A. and Byrareddy, S.N. (2020), "The epidemiology and pathogenesis of coronavirus disease (COVID-19) outbreak", Journal of Autoimmunity, Vol. 109, pp. 102433.

Sahin, S., Ulubeyli, S. and Kazaza, A. (2015), "Innovative crisis management in construction: approaches and the process", Procedia: Social and Behavioral Sciences, Vol. 195, pp. 2298-305.

Schaal, D. (2020, March 18), "Hotels Chains Maneuver to deal with Coronavirus gut punch", Skift.

Schatteman, O., Woodhouse, D. and Terino, J. (2020), Supply Chain Lessons from COVID-19: Time to Refocus on Resilience, Bain \& Company, Inc., Boston, MA, pp. 1-12.

Schmidhuber, J., Pound, J. and Qiao, B. (2020), COVID-19: Channels of Transmission to Food and Agriculture, FAO, Rome.

Schober, K.-S. (2020), The German Construction Industry Must Act Now to Gear up for an Uncertain Future and be in a Position to Shape it Actively, Roland Berger, Munich.

Senthilkumar, V., Reddy, K. and Subramaniam, U. (2020), “COVID-19: impact analysis and recommendations for power and energy sector operation", Applied Energy, Vol. 279, pp. 115739.

Shafi, M., Liu, J. and Ren, W. (2020), "Impact of COVID-19 Pandemic on Micro, Small, and Medium-Sized Enterprises operating in Pakistan", Research in Globalization, Vol. 2, pp. 100018.

Siche, R. (2020), "What is the impact of COVID-19 disease on agriculture", Scientia Agropecuaria, Vol. 11, pp. 3-6.

Umar, T. (2020), "An integrated sustainability-management approach for universities", in Proceedings of the Institution of Civil Engineers-Engineering Sustainability, Thomas Telford Ltd, London, pp. 344-355.

Umar, T. (2022), "The impact of COVID-19 on the GCC construction industry", International Journal of Service Science, Management, Engineering, and Technology, Vol. 13, pp. 1-17.

United Nations Conference on Trade and Development - UNCTAD. (2020), Impact of the Coronavirus Outbreak on Global FDI, UNCTAD, Geneva.

Vafaei, S., Bazrkar, A. and Hajimohammadi, M. (2019), "The investigation of the relationship between sustainable supply chain management and sustainable competitive advantage according to the mediating role of innovation and sustainable process management", Brazilian Journal of Operations \& Production Management, Vol. 16, pp. 572-80. 
Van Der Laan, E., Van Dalen, J., Rohrmoser, M. et al. (2016), "Demand forecasting and order planning for humanitarian logistics: an empirical assessment", Journal of Operations Management, Vol. 45, pp. 114 22.

Veitnam Times. (2020, February 14), "Vietnam's tourism sector could lose US\$5bln due to COVID-19", Veitnam Times.

Vitharana, V., De Silva, S. and De Silva, G. (2015). Health hazards, risk and safety practices in construction sites-a review study.

Xinhua. (2020, June 6), "Maldives construction industry loses 40 mln USD due to COVID-19", Xinhua News.

Yoldascan, E., Kurtaran, B., Koyuncu, M. et al. (2010), "Modeling the economic impact of pandemic influenza: a case study in Turkey", Journal of Medical Systems, Vol. 34, No. 2, pp. 139-45.

Yu, Z. \& Rehman Khan, S. A. (2021), "Evolutionary game analysis of green agricultural product supply chain financing system: COVID-19 pandemic", International Journal of Logistics Research and Applications, pp. $1-21$.

Yu, Z., Razzaq, A., Rehman, A., et al. (2021), “Disruption in global supply chain and socio-economic shocks: a lesson from COVID-19 for sustainable production and consumption", Operations Management Research, pp. 1-16.

Zheng, L., Chen, K. and Ma, L. (2020), "Knowledge, attitudes, and practices towards COVID-19 among construction industry practitioners in China", Frontiers in Public Health, Vol. 8, pp. 981.

Zhu, G., Chou, M.C. and Tsai, C.W. (2020), "Lessons learned from the COVID-19 pandemic exposing the shortcomings of current supply chain operations: a long-term prescriptive offering", Sustainability, Vol. 12, pp. 5858.

Author contributions: Muzaffar Iqbal: Formal analysis, Conceptualization and methodology, writing the original draft. Naveed Ahmad: Supervision and project administration. Muhammad Waqas: Visualization, reviewing, preparing final draft, and formatting. Maira Abrar: Investigation, validation, writing, review and editing. 